\title{
Article \\ Exploring the Political Discursive Lock-Ins on Sustainable Aviation in Sweden
}

\author{
Aneta Kulanovic * and Johan Nordensvärd (D)
}

Citation: Kulanovic, A.;

Nordensvärd, J. Exploring the Political Discursive Lock-Ins on Sustainable Aviation in Sweden. Energies 2021, 14, 7401. https:// doi.org/10.3390/en14217401

Academic Editor: Antonio Zuorro

Received: 29 September 2021

Accepted: 26 October 2021

Published: 5 November 2021

Publisher's Note: MDPI stays neutral with regard to jurisdictional claims in published maps and institutional affiliations.

Copyright: (c) 2021 by the authors. Licensee MDPI, Basel, Switzerland. This article is an open access article distributed under the terms and conditions of the Creative Commons Attribution (CC BY) license (https:// creativecommons.org/licenses/by/ $4.0 /)$.
Department of Management and Engineering, Linköping University, SE-581 83 Linköping, Sweden; johan.nordensvard@liu.se

* Correspondence: aneta.kulanovic@liu.se

\begin{abstract}
This article analyses the political discourse about governing the future of the aviation industry in Sweden and how a polarized and entrenched discursive path dependency around aviation makes it difficult to invest into aviation's possible futures as a sustainable transport. We find three different politically merged frames in the political discussion about governing the road to sustainable aviation: (1) Neoliberal sustainable aviation, (2) Green Keynesian sustainable aviation and (3) National environmentalists' aviation. We can see a discrepancy between two merged frames that believe sustainable aviation will be possible with more or less government support and steering (Neoliberal sustainable aviation and Green Keynesian sustainable aviation) whereas the third merged frame (National environmentalists' aviation) argues that aviation is bound to be environmentally inferior to trains and, therefore, all focus should go to the later. We can see that there is not just a path dependency in the merged frame of National environmentalists' aviation that discounts the possibility that both the role of aviation or its sustainability can change as the technology changes. There is here a static perceived view of technology as being forever clean or dirty. Another path dependency is the linkage of aviation transport with particular political parties where the green party, for instance, oppose aviation while the conservative party wants to support aviation and innovation in aviation. This polarization is actually the largest and most important aspect of the discursive lock-in as this undermines any compromises or large-scale future investments in sustainable aviation.
\end{abstract}

Keywords: aviation; policy; discourse; sustainability; lock-in; industry; emission; electrified aviation

\section{Introduction}

The aim of this paper is to explore the contested political discourse around the future of aviation in Sweden using an interpretative policy analysis of how the different political parties interpret possible aviation futures. Our argument is that there are two discursive path dependencies where one is based around a static view of the aviation technology, whereas the second is based on interparty conflict when deciding on the future of aviation, which leads to a status quo and disregards a long-term decision to make large investment into or de-investment into the technology.

Even though Sweden is already considered a global leader in sustainable energy transformation [1], there are questions about how to move forward to reach the goal of being able to reduce greenhouse gas emissions to net zero emissions. It is well known that the aviation industry needs to undergo major transformations in the upcoming decades to actually reduce its impact on the climate and to reach the below 2 degree goal of the Paris Agreement [2].

After the Paris Agreement, the European Union (EU) put up a goal that aims to reduce greenhouse gas (GHG) emissions by at least 40 percent by the year 2030 and to net zero emissions by 2050. As part of the new European Green Deal, EU's proposed European Climate Law goal is to write into law the goal about achieving net zero GHG emissions by 2050 [3]. Aviation is a part of the sustainable transport ambitions [4], with its 
direct emissions contributing to $3.8 \%$ of total carbon dioxide (CO2) emissions and $13.9 \%$ of transport-related emissions in the EU in 2017 [5].

In response to this, the Swedish government set up a goal to become carbon neutral by 2045, including having a completely fossil-free transport sector in 2045 [6,7]. An initiative called Fossil-free Aviation started to fast-forward the process of Sweden becoming one of the world's first countries with fossil-free aviation [8]. Several actors in the aviation sector have come together and given suggestions to authorities on how to make it possible. However, the initiative is lacking the political perspective and there is very limited research that has analysed the overall national political fault lines and conflicts around the future of aviation vis-à-vis other transport investments such as trains and ships, and motor vehicles such as cars and trucks.

Most research on aviation is often technical and relatively recent. However, we need to have a broader perspective. How we manage the local, national and global environment is directly influenced by how societies and politics allocate natural, human and financial resources. Focusing and solving one problem can ignore other problems that are related and in turn create other problems [9]. In the research society, there exists a wide scope of research about proposals of air travel tax implementations [10-12], emission reduction schemes [13-15], alternative aviation fuels for aviation [16-19], novel aircraft types [20-22], and also travel behavior [23-25].

The Swedish state-owned airports company Swedavia have the target that all domestic flights will be fossil free by the year 2030 [26]. Airlines such as SAS and BRA are offering their customers the possibility to purchase bio-based sustainable jet fuel as an alternative to fossil fuel-based jet fuel [27]. There are also initiatives for electric aircrafts undertaken by industry leaders and research organizations, including as a part of Fossil Free Aviation 2045 and the Nordic Network for Electric Aviation NEA [28].

Sweden's central national policy to reduce travel volume targeted a tax levied on passenger numbers, an indirect financial disincentive, and it is at the discretion of the airlines to pass on the cost of tax levies [14]. Implemented in 2018, little is known about its effectiveness. Technology development that does not consider societal norms and consumer preferences may result in rejection by individuals or society at large $[29,30]$. The policies that aim to support the development of sustainable aviation, and what policies to be developed to push this development and reach the 2045 goal, are widely debated at the political level. Even if aviation plays an important role in a long and sparsely populated country such as Sweden, there is little research that focuses on the political discourse around energy transitions and different sustainable solutions for the aviation industry in Sweden in general, and to discern whether there are any discursive path dependencies and discursive lock-ins that prevent aviation reaching its full potential. The focus in this paper is to define the lock-ins at the political level that prevent the aviation industry to move forward into a future with sustainable aviation.

In this article, our analysis will expand upon the concept of path dependency and carbon lock-ins [31,32]. Metze discusses the consequences of discursive lock-ins, which leave "little room for the introduction of alternatives" [33]. Buschmann and Oels have developed the idea of discursive lock-ins further and defined a discursive lock-in as when "such institutionalized mechanisms of discursive reproduction include mechanisms of reproduction related to a mental map (or discourse) based on increasing returns" and to reach a discursive turning point "the mechanisms of reproduction of the hegemonic discourse must be disrupted effectively" [34]. They argue that this can be achieved "through deliberation, through performative action and through external shocks that work as discursive" [34]. A discourse plays a role as an important aspect of a lock-in as it connects and aligns infrastructures, institutions and behavior [35-38]. There is the argument that when a discourse has secured its reproduction in one or several institutions, it has reached hegemony [39].

In this article, we are applying the method of interpretative policy analysis [40], to analyze the political discourse around the future of aviation in Sweden. A discourse 
analysis of policy could be understood to deconstruct texts to understand how texts are structured in a particular way and what social and political implications this will have $[41,42]$. We will look at the political stance on aviation and how this plays out in the political discourse, and we will use the case of Västerås airport to show how locked-in the political discussion is and how our analytical framework can be used. We believe that Västerås airport is a good case study as here both of the discursive fault lines can be seen, and it also highlights the uncertain future of this mode of transport.

The article argues that the political discourse about governing the future of the aviation industry in Sweden and how a polarized and entrenched discursive path dependency around aviation makes it difficult to invest into aviation's possible futures as a sustainable transport. We find three different politically merged frames in the political discussion about governing the pathway to sustainable aviation: (1) Neoliberal sustainable aviation, (2) Green Keynesian sustainable aviation and (3) National environmentalists' aviation. We can see a discrepancy between two merged frames that believe sustainable aviation will be possible with more or less government support and steering (Neoliberal sustainable aviation and Green Keynesian sustainable aviation) where the third merged frame (National environmentalists' aviation) argues that aviation is bound to be environmentally inferior to trains and, therefore, all focus should go to the later.

We can see that there is a path dependency in the merged frame of National environmentalists' aviation that discounts the possibility that both the role of aviation or its sustainability can change as the technology changes. There is here a static perceived view of technology as being forever clean or dirty. Another path dependency is the linkage of aviation transport with particular political parties where the green party, for instance, opposes aviation while the conservative party wants to support aviation and innovation. We can see this in the case study of Västerås airport where the divide on the future of aviation and the airport is divided between political fault lines. This polarization is actually the largest and most important aspect of the discursive lock-in as this undermines any compromises or large-scale future investments in sustainable aviation.

\section{Method, Theory and Material}

\subsection{Method and Theory}

As mentioned in the introduction, our analysis will expand upon the concept of path dependency and carbon lock-ins. These lock-ins are characterized by the process of "technological and institutional co-evolution driven by path-dependent economies of scale" [31]. Unruh suggests that lock-in are driven by the process of "technological and institutional co-evolution driven by path-dependent" economies of scale [31]. Lock-ins create "persistent market and policy failures that can inhibit the diffusion of carbon-saving technologies despite their apparent environmental and economic advantages" [31]. Unruh argues that an escape from carbon lock-in is needed [32]. In this article, we apply the method of interpretative policy analysis. Interpretative policy analysis diverges from mainstream positivist policy at analysis by focusing on how policy actors interact by addressing the social meaning of policies and the practices in which this meaning is embedded' [40]. Moreover, such a perspective seeks to "develop a deeper, interpretative understanding of policy practices and policy process in general, having extended their scope over time to include perspectives on discourse, narration, governmentality and practice" [40]. A discourse analysis approach tends to emphasize "the indexical or situated nature of social categories in linguistic interaction" [41]. A discourse analysis of policy could be understood to deconstruct texts to understand how texts are structured in a particular way and what social and political implications this will have [42]. Discourse analysis has an interest in how institutions and rules are spread through the use of language [42].

To analyze our material we apply the method of framing and metaphors, which can be seen as viable discursive tools to perform interpretative policy and to address social meaning of policies and the practices in which the meaning is embedded [43,44]. In our analyses of frames, merged frames and metaphors, we use a conceptual understanding 
of discourses. Frames are seen as "schemata of interpretation" that guide individuals to "locate, perceive, identify and label" [45] conditions and events around us. Frames are often used as a "strategic and deliberate activity aimed at generating public support for specific policy ideas" [46]. Merged frames, in turn, comprise elements of each of the input schemas, while they contribute to a new frame that results in its own unique and separate structure. Metaphors as such need to be understood in the context of larger frames [47], seen as "devices or units of language that are deployed within particular conversations and contexts" [48]. This means that metaphors are not isolated discourses from its context but instead are directly connected to specific ideological frames. Merged frames, and their related metaphors, "are variegated towards the local political context and therefore always adapted and contextualized in locally meaningful ways" [47]. Our method is an adaptation of frame merging and metaphor analysis inspired by Nordensvärd and Ketola [47].

The different metaphors can represent frames but also merged frames, where frames are "embodiment" while merged frames are taking on a "variegated form" [47]. We chose this framework because it explains how a frame as neoliberalism is contextualized and creates multiple understandings of the aviation discourse. The relationship between frames, merged frames and metaphors are mapped out in Table 1.

Table 1. Frames, merged frames and metaphors. Taken from Nordensvärd and Ketola (2019).

\begin{tabular}{|c|c|c|c|}
\hline Frames & Merged Frames & Metaphors & The Link \\
\hline $\begin{array}{l}\text { Frames are schemata of } \\
\text { interpretations that help to } \\
\text { locate, perceive, identify and } \\
\text { label events and conditions [45]. } \\
\text { Policy framing is a strategic and } \\
\text { deliberate activity aimed at } \\
\text { generating public support for } \\
\text { specific policy ideas [46]. } \\
\text { Framing trancends the } \\
\text { boundaries of agenda setting } \\
\text { and links with "stable } \\
\text { ideological repertoires" [46]. } \\
\text { Policy makers need to use } \\
\text { culturally accepted } \\
\text { repertoires [49]. Frames are } \\
\text { dialogical in nature and } \\
\text { anticipate potential opposition } \\
\text { to undermine support for } \\
\text { policies [46]. }\end{array}$ & $\begin{array}{l}\text { Merged frames are the } \\
\text { discursive combination of two } \\
\text { separate schemas or } \\
\text { incorporation of words and } \\
\text { elements of one schema into } \\
\text { that of another [50]. A merged } \\
\text { frame is a hybrid that } \\
\text { comprises elements from each } \\
\text { of the input schemas but also } \\
\text { becomes its own unique } \\
\text { structure [50,51]. Merged } \\
\text { frames help to combine } \\
\text { seemingly incompatible and } \\
\text { competing sets of cultural } \\
\text { beliefs [52] and circumvent } \\
\text { the dilemma of alternative } \\
\text { and competing schemas [53]. }\end{array}$ & $\begin{array}{l}\text { Metaphors can be } \\
\text { considered as "a way of } \\
\text { comparing two different } \\
\text { concepts" [54] and } \\
\text { understanding one } \\
\text { experience in terms of } \\
\text { another experience [55]. } \\
\text { Metaphors are "devices or } \\
\text { units of language that are } \\
\text { deployed within particular } \\
\text { conversations and } \\
\text { contexts" [48]. Metaphors } \\
\text { are chosen to achieve certain } \\
\text { communication goals within } \\
\text { particular contexts rather } \\
\text { than being predetermined } \\
\text { by bodily experience [56] } \\
\text { that is aligned with } \\
\text { frames/merged frames. }\end{array}$ & $\begin{array}{l}\text { Frames, merged frames and } \\
\text { metaphors create particular } \\
\text { policy contexts used to make } \\
\text { sense of particular policy } \\
\text { alternatives and are part of the } \\
\text { "exercise of political power } \\
\text { and the language used to } \\
\text { legitimate that process" [57]. } \\
\text { Metaphors should be } \\
\text { understood as embodiments } \\
\text { of particular ideological } \\
\text { frames. Merged frames and } \\
\text { related metaphors are } \\
\text { variegated towards the local } \\
\text { political context and therefore } \\
\text { always adapted and } \\
\text { contextualizing. }\end{array}$ \\
\hline
\end{tabular}

Moreover, the different discourses of aviation have been adapted to the ideological political contexts of environmental solutions. Aviation as such does not have a specific environmental political discourse, instead, we combined the aviation discussion to the different ideological views that are presented under frames. These frames represent different contexts theoretically; practically they are not as pure in the real political discussion where there is usually a mix of different frames that then become merged frames.

\subsection{Analytical Framework}

Table 2 represents the different policy discourses, how we are framing them, the metaphors and the link to the aviation context. We used Table 2 as our analytical framework that we applied to the material. In Table 2, we present four different worldviews on global environmental change and its relationship to politics. First, we have the market liberal aviation discourse which is in the frame of market liberals and the idea that modern science, technology and money are improving the global environment. Fostering economic growth will improve the environment in the long run [9]. In this political discourse it is believed that 
globalization promotes growth, enhances efficiency and prevents poverty. The right way forward is to correct policy and market failures and implement market-based incentives to promote clean technologies [9]. The link to aviation is to get the prices right by internalizing external costs with, for instance, carbon trading. It is believed that the best way to transform the aviation industry into a sustainable one is through market mechanisms such as carbon markets and carbon trade. "The belief is that economic incentives, self-interests and market mechanisms will achieve an efficient, least-cost solution to the climate crisis" [58]. Emission targets and energy efficiency targets have an important role to play, but it is the price system that has to make it easier to achieve our goals [58].

Table 2. The analytical framework.

\begin{tabular}{|c|c|c|c|}
\hline Policy Discourse & Frame & Metaphor & Aviation \\
\hline $\begin{array}{l}\text { Market liberals } \\
\text { aviation discourse }\end{array}$ & $\begin{array}{l}\text { Inspired by market } \\
\text { liberals and the idea that } \\
\text { modern science, technology } \\
\text { and money are improving the } \\
\text { global environment. Fostering } \\
\text { economic growth will } \\
\text { improve the environment in } \\
\text { the long run [9]. }\end{array}$ & $\begin{array}{l}\text { Believes that globalization } \\
\text { promotes growth, enhances } \\
\text { efficiency and prevents } \\
\text { poverty. The way forward is } \\
\text { to correct policy and market } \\
\text { failures and implement } \\
\text { market-based incentives to } \\
\text { promote clean } \\
\text { technologies [9]. }\end{array}$ & $\begin{array}{l}\text { "Getting prices right" by carbon } \\
\text { trading. } \\
\text { The best way to transform the } \\
\text { aviation industry to become } \\
\text { sustainable is through market } \\
\text { mechanisms, such as carbon } \\
\text { markets and carbon trade. Emission } \\
\text { targets and energy efficiency targets } \\
\text { have an important role to play, but } \\
\text { it is the price system that has to } \\
\text { make it easier to achieve our } \\
\text { goals [58]. }\end{array}$ \\
\hline $\begin{array}{c}\text { Institutionalists' } \\
\text { aviation discourse }\end{array}$ & $\begin{array}{l}\text { Inspired by institutionalists } \\
\text { and the idea that guided } \\
\text { globalization enhances human } \\
\text { welfare. Weak institutions and } \\
\text { no global cooperation are the } \\
\text { problem [9]. }\end{array}$ & $\begin{array}{c}\text { We need to harness } \\
\text { globalization, promote strong } \\
\text { global institutions, regimes } \\
\text { and norms that can manage } \\
\text { the global } \\
\text { environment/distribute } \\
\text { technology effectively. Build } \\
\text { state capacity and employ } \\
\text { precautionary principles [9]. }\end{array}$ & $\begin{array}{l}\text { Use tax, subsidies/incentives and } \\
\text { regulations to transform the } \\
\text { aviation industry sustainably. This } \\
\text { could be done either through active } \\
\text { state involvement and/or stricter } \\
\text { regulations/taxations. Planning } \\
\text { must involve a system of carbon } \\
\text { taxation that provides the finance } \\
\text { for public investments in renewable } \\
\text { energy and subsidies for } \\
\text { clean technologies. }\end{array}$ \\
\hline $\begin{array}{l}\text { Bioenvironmentalists' } \\
\text { aviation discourse }\end{array}$ & $\begin{array}{l}\text { Inspired by the idea that } \\
\text { ecological crisis threatens } \\
\text { human survival. } \\
\text { Overpopulation, } \\
\text { overconsumption and } \\
\text { excessive economic growth is } \\
\text { seen as the cause of the } \\
\text { problem [9]. }\end{array}$ & $\begin{array}{l}\text { Wants to create a new global } \\
\text { economy with limits to } \\
\text { growth. Reduce consumption } \\
\text { and limit population. Agree to } \\
\text { collective coercion so as to } \\
\text { control greed, reproduction } \\
\text { and exploitation [9]. }\end{array}$ & $\begin{array}{l}\text { Heading towards either a collapse } \\
\text { of the present capitalist system or a } \\
\text { collapse of our global climate. This } \\
\text { will mean that aviation travel will } \\
\text { have to be part of a degrowth } \\
\text { scenario, be cut back or replaced or } \\
\text { modified to fill the overall economic } \\
\text { re-orientation. There will not be a } \\
\text { specific aviation discourse per se. }\end{array}$ \\
\hline $\begin{array}{l}\text { Social greens' aviation } \\
\text { discourse }\end{array}$ & $\begin{array}{l}\text { Inspired by the idea that } \\
\text { social injustice, at both local } \\
\text { and global levels, creates } \\
\text { environmental crisis. } \\
\text { Globalization accelerates } \\
\text { exploitation, inequalities and } \\
\text { ecological injustice [9]. }\end{array}$ & $\begin{array}{l}\text { Believes in rejecting } \\
\text { industrialism and reverse } \\
\text { economic globalization. } \\
\text { Wants to restore local } \\
\text { community autonomy and } \\
\text { empower marginalized voices. } \\
\text { Promote ecological justice and } \\
\text { local and indigenous } \\
\text { knowledge systems [9]. }\end{array}$ & $\begin{array}{l}\text { Would need to change ownership } \\
\text { structure of the aviation industry } \\
\text { and change how investment and } \\
\text { travel is conducted through a } \\
\text { socially just and democratic reform } \\
\text { of transport. The focus lies here on } \\
\text { resources and transport, the use of } \\
\text { natural resources is subject to } \\
\text { decentralized democratic decisions } \\
\text { that will lead to lower consumption } \\
\text { and higher welfare [58]. }\end{array}$ \\
\hline
\end{tabular}


Secondly, we have the institutionalists aviation discourse. This frame is inspired by institutionalists global environmental worldview and the idea that guided globalization enhances human welfare. They see weak institutions and no global cooperation as the problems. They want to harness globalization, promote strong global institutions, regimes and norms that can manage the global environment/distribute technology effectively to developing countries. They also believe in building state capacity and employ precautionary principles [9]. The link to aviation is what Storm [58] calls Green Keynesianism, meaning forcing technology development through regulation, carbon taxation and redistribution. The institutional solution is to use tax, subsidies or incentives and regulations to transform the aviation industry to become sustainable, which can be completed either through active state involvement or through strict regulations or taxations, or a combination of both Planning for sustainable aviation must involve a system of carbon taxation that provides the finance for public investments in renewable energy and subsidies for clean technology, including aggressive industrial policy [58].

The third discourse is the bioenvironmentalists' aviation discourse, which is inspired by the idea that ecological crisis threatens human survival and differs more from the first two discourses. Overpopulation, overconsumption and excessive economic growth is seen as the cause of the problem and that globalization is the reason for unsustainable growth, investment, trade and debt [9]. The best solutions are seen as those creating a new global economy with limits to growth, reduce consumption and limit population and agree to collective coercion so as to control greed, reproduction and exploitation [9]. The world can only be sustainable by low growth, no growth or even degrowth for Western developed countries. Scholars such as Bello [59] and Speth [60] argue that we are heading towards either a collapse of the present capitalist system or a collapse of our global climate. This will mean that aviation travel will have to be a part of a degrowth scenario, which means to be cut back, replaced or modified to fill the overall economic re-orientation. There will not be a specific aviation discourse per se.

Lastly, we have the social greens aviation discourse. This discourse is inspired by the idea that social injustice, both at local and global levels, creates environmental crisis. Globalization only accelerates exploitation, inequalities and ecological injustice [9]. In this frame it is believed that rejecting industrialism and reverse economic globalization is the only solution. The goal is to restore local community autonomy and empower marginalized voices while promoting ecological justice and local and indigenous knowledge systems [9]. There exists a conflict between capitalism's drive for growth and ecological change, which would need to change the ownership structure of the aviation industry and change how investments and travel is conducted through a socially just and democratic reform of transport. The focus lies on the fact that resources and transport are "collectively owned and cooperatively managed [58]. The use of natural resources is subjected to decentralized democratic decision making, which will lead to lower consumption and higher welfare [58].

\subsection{Material}

In this article we focus on Sweden as a case study. We focused on the political discussion and lock-in on sustainable aviation in Sweden. To show how our analytical framework could be applied we used Västerås airport as an example of the lock-in to use our discursive framework to analyse the case of the political decision of closing down Västerås airport and the following referendum. We chose Västerås airport since it is a case that shows the complexity of the matter when there is a locked-in political discussion, which shows how aviation is considered a dirty, not environmentally-friendly means of transport. Västerås airport is only used as an example to show the lock-in political discussion and path dependency in the political parties.

The material consists of canvased material we could find on the discussion of different topics connected to aviation, airports and fuel alternatives for aviation. The material was gathered in two different ways-one was to search for material through the Swedish government's site Sveriges Riksdag, where all documents, political discussions and laws 
can be found. We used the following search words: aviation, electric aviation, airports, climate, fossil-free fuel, SAF. We also searched through the different homepages of the parties searching for aviation, airports and fuel alternatives for aviation.

We also researched the political parties and their political programs on their websites where additional information could be found on where they stand in the climate discussion and on aviation.

As a third step, we then researched different news articles that brought up the political discussion and conducted research of the literature in Scopus and Google Scholar. The focus was on the political discussion and the government's role in the sustainable transformation in aviation, meaning that the research articles that focused on technical questions did not make the cut. The search words and how many results we found are presented in Table 3.

Table 3. This table presents the source of our findings, the search words and the results from the searches.

\begin{tabular}{ccc}
\hline Source & Search Words & Results $^{\mathbf{1}}$ \\
\hline Governmental documents & $\begin{array}{c}\text { Aviation, electric, airports, fossil-free fuel, } \\
\text { climate, SAF }\end{array}$ & 283 \\
\hline Political parties websites & $\begin{array}{c}\text { Climate, Aviation, Fossil-free fuel, } \\
\text { electric aviation }\end{array}$ & 133 \\
\hline News articles & $\begin{array}{c}\text { Electric aviation, political parties, } \\
\text { government, fossil-free fuel aviation }\end{array}$ & 350 \\
\hline Research databases & $\begin{array}{c}\text { Aviation, electric, airports, climate, } \\
\text { fossil-free fuel, policy, SAF }\end{array}$ \\
\hline
\end{tabular}

${ }^{1}$ The total results of the search, not all were relevant for this article, for instance, the articles that had too much of a technical focus.

\section{Results}

In our analysis, we found that there exist three merged frames in the aviation discussion. The frames are: Neoliberal sustainable aviation, Green Keynesian sustainable aviation and National environmentalists' aviation. In the first frame, Neoliberal sustainable aviation, one can argue that the government has a silent role supporting the industry and research community. The second frame, Green Keynesian sustainable aviation, has more of a steering approach. In this frame, the government has a steering role through taxation and regulations while also encoring and supporting the industry and research society. The third merged frame has a firm approach for less aviation, the approach is more controlling and involved in the development than the first two frames. Table 4 shows an overview of the merged frames and applied metaphors.

Table 4. Merged Frames and results.

\begin{tabular}{ccc}
\hline Merged Frames & Metaphors \\
\hline Neoliberal sustainable aviation & $\begin{array}{r}\text { They believe in investing in new technology and innovation for aviation. Letting } \\
\text { the industry make the way while the government have a more laid-back role with } \\
\text { less interference from the government in the policy process. They believe that this } \\
\text { is a global matter and that globalization promotes growth and enhances efficiency. } \\
\text { They want to help the industry move forward by encouraging solutions that will } \\
\text { lead others to invest in future sustainable solutions. }\end{array}$ \\
Green Keynesian sustainable aviation & $\begin{array}{c}\text { The strategy involves a more active government that is closer to ecological } \\
\text { modernization and Green Keynesianism. It means that the state will have a } \\
\text { steering role by adding tax on fuel and regulations to transform the aviation } \\
\text { industry into a more sustainable one. In this frame the policy tools to reach } \\
\text { sustainable aviation are focused on believing in regulation, innovation and carbon } \\
\text { taxation. They also believe that this is a global matter but that the government } \\
\text { needs to steer the development in, what they believe to be, the right direction with } \\
\text { help from science and the industry. }\end{array}$ \\
\hline
\end{tabular}


Table 4. Cont.

Merged Frames

National environmentalists aviation
Metaphors

In this frame, globalization is often the problem to our environmental problems. The government wants to have more control and steer the evolution of an environmental friendly future, even if it means less aviation. In this frame, the government has a firm hand in saying where the future path is and wants to lead the transformation. They believe that the solution is to cut back and replace aviation with trains.

\subsection{Neoliberal Sustainable Aviation}

Three of the political parties, the Moderate party, the Swedish democratic party and the Christian Democratic party, use the frame of Neoliberal sustainable aviation to support their arguments and proposed policies for sustainable aviation. We can see a market liberal frame that integrates a neoclassical economic view with science and technology to understand and move forward in the locked-in sustainable aviation pathway. This frame has a focus on seeing the path of sustainable development as something that economic growth and new technology can solve, giving the industry and science the biggest role to be able to move forward, meaning that the government has more of a laid-back role and is not as involved in the process more than overviewing and giving help as support from the government. The government has "faith in the capacity of the invisible hand to adjust the natural thermostat" [58].

In the aviation discussion about taxation, the Moderate Party in Sweden do not believe in having flight taxes since they believe it to be ineffective. They argue that Sweden's emissions from aviation are regulated by the EU's emissions trading system which they say means that if Sweden reduces its emissions, other EU countries can increase theirs. They believe that aviation tax in Sweden only means a higher price for Swedish travelers, which in reality only moves emissions abroad. The net effect on the environment will, thus, be zero but it will affect Swedish travelers. The Moderate Party do, however, agree that just like other parts of society, aviation must reduce its emissions of fossil carbon dioxide. They want it to happen through research and innovation, with conversion to biofuel that is needed faster, not through what they believe to be inefficient punitive taxes [61]. They do, however, believe in having landing fees to encourage more investments in the blending of biofuels. They also want to give consumers more information during a ticket purchase about how much the flight travel generates emissions [62]. Similar to the Moderate party's arguments for policy tools, the Christian Democratic Party suggests investments in both biofuels for aviation and on electric aviation. They do not believe in aviation fuel taxation, but they do believe in having climate take-off and landing fees. In the discussion about regional airports, they also believe that airports should be protected [63]. For instance, they believe in using Bromma airport as a base for testing electrified aviation [64].

The Swedish democrats have the same view on flight taxes and believe it to be ineffective. They believe in even less involvement from the government than the Moderate party since they do not even believe in landing fees either. Since Covid-19 hit the aviation industry hard, they do not believe in making it worse by adding restrictions; they want the aviation industry to recover in order to be able to prioritize new innovations instead. They believe it to be a global problem and that the discussion about different solutions needs to be taken up at an EU and international level. In the discussion about closing down regional airports and moving all air traffic to bigger airports, they believe it to be a stupid decision since the bigger airports need to focus on innovation and new technology, while regional airports should be used to strengthen the Swedish infrastructure. Closing down airports and building houses instead would have other consequences for the environment, while we still need the airports and can just improve and make them sustainable [65].

The political parties in this frame believe that the government should have a more laid-back roll and support future innovation for better solutions for a more sustainable aviation. They believe that this is a global matter, and that globalization promotes growth 
and enhances efficiency. They want to help the industry move forward by encouraging solutions that will lead others to invest in future sustainable solutions.

\subsection{Green Keynesian Sustainable Aviation}

Analyzing the political discussion about sustainable aviation, we found the Green Keynesian sustainable aviation frame. Three of the Swedish political parties, the Liberals, the Social Democratic Party and the Centre Party use this frame to support their solutions and policies for sustainable aviation. Here we can see a more active state influenced by Institutionalism and Green Keynesianism [58], and, to some degree, neoliberal aspects. In this frame, the policy tools to reach sustainable aviation are focused on believing in regulation, innovation and carbon taxation. The government has more of a steering role in this frame.

The Liberals believe that aviation is an unbeatable means of transport when it comes to traveling long distances in a short amount of time. Considering the infrastructure and the economical perspective, they believe it to be the most effective alternative. Regarding the question about closing down airports, they believe that airports tie together Sweden, create job opportunities and increase possibilities for tourism in the whole country. They want Sweden to push for flight tax in the EU that does not tax all flight traffic the same but promotes flights with lower climate and environmental impact. On a national level, the Liberals want to have a differentiated system with landing fees considering how much biofuel is being used in airplanes combined with a reduction obligation system and climate decelerations. The liberals believe in retaining and supporting the airports by bringing forward a long-term and sustainable strategy to ensure their development and survival. They also bring up the discussion about electric aviation that can make short flights between regions be more profitable, which brings up the importance of keeping the smaller airports. They believe that electric aviation can be an important factor for the development of the country's regions and offer fast transport, and that electric aviation is an area under strong development where it is important that the state contributes to research and development as this has the potential to reduce the climate impact of aviation and, at the same time, become a new industry in Sweden [66]. The Centre Party has a similar policy in that aviation is an important transport alternative; however, it needs to become more effective and environmentally friendly. They believe in having a mandatory demand for admixture of renewable biofuel. They argue that it is a climatic and economically effective way to reduce the aviation climate impact and to transform to a sustainable aviation industry. They even argue that they believe that Swedavia, which owns 10 airports in Sweden, should increase the opportunity for discounts for start and landing fees with the best environmental quality [67].

The Swedish Social Democratic Party wants it to be easier to choose the train, while they also take up the discussion about working harder to use sustainable fuel alternatives for aviation. They also believe that it takes collective effort to work for this transition and that countries need to work for this together at an EU level [68]. The government gave the Swedish Transport Agency the assignment to conduct a pilot study that highlights to what extent state-procured air traffic can contribute to the objective to reduce the climate impact of aviation have while still maintaining its availability in the country. The study includes those airlines that have been purchased by the state and analysis as to what extent the use of biofuels and electrification by the already existing air traffic can contribute to reducing greenhouse gas emissions. They bring up the discussion that there are some uncertainties about whether the existing EU rules provide space for demands on fossil-free fuels. Setting aside the uncertain legal matter, they conclude that Sweden should have good conditions to identify and push to open up about climate-related demands in the European parliament, considering the council regulation nr 1008/2008 of the 24 September 2008 about collective rules for the provision of air traffic [69].

The political parties in this frame want to be involved in the future sustainable development of aviation and steer the path to reach the goal. They also believe that this is 
a global matter, but that Sweden needs to steer the development in, what they believe to be, the right direction.

\subsection{National Environmentalists Aviation}

In the sustainable aviation discussion, we also find a third discourse, the National environmentalists' aviation frame. This frame has a national perspective, believing that globalization is the problem to our environmental problems. In this frame, the government wants to have more control and to steer the evolution of an environmentally-friendly future, even if it means less aviation. The two political parties that are using this frame are the Green Party and the Left Party.

In November 2020, the government decided that SEK 73.9 million from the government's budget would go to communication in 2021. The decision was made on a proposition from the Central Party, the Liberals, the Green Party and the Social Democrat Party. Most of the money, around SEK 30.8 million went to developing already existing transport infrastructure, such as railways [70]. During the debate, the focus shifted from electrification to trains since the Moderate Party wants to focus more money on electrification instead of putting the money on night trains, which the Left Party did not agree to and questioned. The debate turned its focus from aviation to trains. This particular discussion is just an example of how the debate usually goes when the topic is about sustainability, aviation and transport. The political parties have different views on how to move forward with the aviation industry in order to reach the goal in 2045. The Left Party wants to make it cheaper to choose the environmentally-friendly way of traveling [71]. They believe that Sweden needs to push for ICAO and reduce the aviation industry's environmental impact and have a tax on aviation fuel. However, if Sweden is the only country to have aviation tax, there is a risk that aviation companies might land in neighboring countries because of financial reasons. They believe that Sweden needs to have an open discussion with neighboring countries about having similar tax levels. The Left Party believes that the companies will be stimulated to fill their planes with travelers by having a climate tax through start and landing charges and, in that case, will reduce the impact on the environment. The airplanes that take off will then be put to maximum use, making them more effective. They believe that it is not as effective as having a fuel tax; however, it is a clear economic policy instrument [72]. They believe that the best solution is to fly less and use trains instead. The aviation industry was severely affected by the COVID-19 pandemic at the beginning of 2020, the Swedish government decided to help the industry with tax money, which the Left Party did not agree with. They criticized that a part of that money went to regional airports, which they believe are unnecessary since people can use trains instead of domestic flights [73].

Up until March 2021, there have been pending debates about closing down the airport in Västerås, pushed by the Green Party in Sweden. The Green Party shares the opinion with the Left Party about using more trains and fewer airplanes. They want to build new railways for high-speed trains, and they want airports to introduce congestion charges that will increase prices on commuting and business air travels. They also believe in introducing taxes on flight fuel in the EU, both energy taxes and carbon dioxide taxes, for all flights in Europe [74]. The Green Party's argument is that the airport costs too much money for the government and that the money could go to healthcare instead. The Centre Party, on the other hand, argues that the investigations show that the companies that are dependent on a fully equipped airport generate around 3-4 times as much income for the government, region and municipality, compared to what it costs [75].

This frame focuses on the government as playing a bigger part and not only steering or supporting the industry in a sustainable transformation in aviation. In this frame, the government has a firm hand in saying where the future path is and wants to lead the transformation. They believe the solution is to cut back and replace aviation with trains. 


\subsection{The Case of Closing down Västerås Airport and the Follow up Referendum}

We have used our discursive framework to analyse the case of the political decision of closing down Västerås airport and the following referendum. We present the results in Table 5 .

Table 5. The Case of Västerås airport.

\begin{tabular}{|c|c|c|}
\hline Frame & Arguments for Keeping the Airport & $\begin{array}{c}\text { Arguments for Closing Down the } \\
\text { Airport }\end{array}$ \\
\hline National environmentalists' aviation & & $\begin{array}{l}\text { Green Party-The public should not } \\
\text { subsidize airport in the middle of a } \\
\text { climate crisis [76]. } \\
\text { The future of aviation is bound to be } \\
\text { negative and electrical aviation is too far } \\
\text { into the future [77]. } \\
\text { Aviation will always be dirty compared } \\
\text { to other transports [77-79]. }\end{array}$ \\
\hline Green Keynesian sustainable aviation & $\begin{array}{l}\text { Swedish Democrats/Moderate } \\
\text { Party-Airport/aviation is a social service } \\
\text { that needs to be kept for the public, for } \\
\text { example, the importance of aviation for } \\
\text { medical supplies and fire fighting through } \\
\text { aviation [80]. }\end{array}$ & $\begin{array}{l}\text { Social Democrats/Left Party/Liberal } \\
\text { Party-Costs too much for the taxpayers, } \\
\text { money that could be spent on social } \\
\text { services instead [81]. }\end{array}$ \\
\hline Neoliberal sustainable aviation & $\begin{array}{l}\text { Moderate Party/The Central Party-There } \\
\text { will be a cost for closing down the airport. } \\
\text { Even more costly to reopen an airport in the } \\
\text { future. Cost of people losing their jobs [80]. } \\
\text { Christian Party/Moderate Party-If Västerås } \\
\text { continues to grow we need to have } \\
\text { infrastructure in place and develop further } \\
\text { for the economy and corporations [80]. } \\
\text { Central Party-Cannot pend transport } \\
\text { against each other, the airport could be used } \\
\text { for electric aviation and innovation [78]. }\end{array}$ & $\begin{array}{l}\text { The Green Party-The airport is too } \\
\text { costly for the taxpayers and the } \\
\text { environment while building commercial } \\
\text { and residential properties will be more } \\
\text { cost-effective and important for } \\
\text { developing the city and economy [82]. }\end{array}$ \\
\hline
\end{tabular}

The Green Party pushed for closing Västerås airport with arguments that it is not needed because of already existing good train connections that can be used instead [78]. They highlighted that the public should not subsidize the airport in the middle of a climate crisis [76], that the future of aviation is bound to be negative, that electrical aviation is too far into the future and there are doubts that it will be viable at all, and that aviation will always be inferior environmentally speaking compared to other modes of transportation such as trains [77]. They compare transport alternatives against each other and state that aviation will always be considered as dirty while transport such as trains are clean The Green Party stated that "what drives innovation is often political decisions or regulations that forces the industry to move forward" [78]. They mean that nothing will change or develop when it comes to sustainable aviation until the government pushes the industry to move forward and to develop more sustainable solutions. Västerås airport is controlled by the municipality of Västerås, which wanted to close down the airport because it costs the municipality money and that the municipality would gain if it was closed down [79].

The Left Party, the Liberal Party and the Social Democrats agreed that the airport costs taxpayers too much money, money that could be spent on social services instead [81]. The Green Party also stated that the airport is costly for the taxpayers and the environment while building commercial and residential properties will be more cost-effective and important for developing the city and the economy [82].

Closing down Västerås airport was not favorable with the Moderate Party, the Christian Party or the Swedish Democrats, led by the Center Party, who were the strongest voice against the close down. The Swedish Democrats and the Moderate Party argued that air- 
port and aviation is a social service that needs to be kept for the public. They used examples such as the importance of aviation for medical supplies or firefighting through aviation [82]. The Christian Party and the Moderate Party stated that if Västerås continued to grow we needed to have a working infrastructure in place and develop further for the economy and corporations. The Central Party and the Moderate Party also highlighted that it would be very costly to close down the airport concerning all the people who would be unemployed, and it would cost to reopen an airport later in the future [82]. The Central Party also stated that we should not compare transport options against each other, that trains can never replace aviation fully and that the airport could be used as a starting point for innovation and electric aviation [78]. The Central Party pushed through with a referendum [78] where the people in Västerås municipality voted to keep Västerås airport believing that it is better to keep the jobs and work for a more sustainable airport [79]. Västerås airport plays a huge role for both the regional development and healthcare, questions concerning the region [83].

What was particularly interesting was that the fault lines were down to the political parties being for or against Västerås airport, but most parties used arguments for the different merged frames to make a case for either keeping the airport open or closing it. For an example, the Green Party used arguments from all of the merged frames. Although in the discussion about keeping the airport we could find that the Moderate party were against closing down Västerås airport, they also pushed for using the airport as a base for sustainable aviation and airport [78]. Meaning that arguments from the third frame, Neoliberal Sustainable Aviation, were also involved in the decision about keeping the airport.

This shows the discursive complexity and lock-in on the fault lines between the greensocialist merged frame on one side and the center-right merged frame on the other side, which leads to no clear outcome.

\section{Discussion and Conclusions}

We argue that the political discourse about governing the future of the aviation industry in Sweden, and how a polarized and entrenched discursive path dependency around aviation, makes it difficult to invest into aviation's possible futures as a sustainable transport. We find that three different political merged frames position themselves in two different factions concerning the future of aviation. We argue that the merged frames of (1) Neoliberal sustainable aviation and (2) Green Keynesian sustainable aviation might disagree on the role of the state in supporting or intervening in the aviation industry, but they agree on investing more into aviation. The merged frame (3) National environmentalists' aviation sees that aviation has less future viability and wants to transfer funds and resources away from aviation towards trains and, therefore, use both taxes, regulations and the withdrawal of funding to reduce aviation transport and industry. There is here a static perceived view of technology as being forever clean or dirty. Another path dependency is the linkage of aviation transport with particular political parties, where the green party, for instance, oppose aviation, while the conservative party wants to support aviation and innovation. We can see that there is an ongoing division on the future of aviation that is hindered by the trenches between these two rival approaches to the future of aviation industries, which prevents a clear course of either increased investment on one side or a clear de-investment on the other side. We argue that this is due to the conflict between discursive fronts on the fault lines of political parties on the left and the middle and right-wing segment. This shows a path dependency of the linkage of aviation transport with particular political parties where the green party, for instance, oppose aviation while conservatives want to support aviation and innovation.

This polarization is actually the largest and most important aspect of the discursive lock-in as this undermines any compromises or large-scale future investments in sustainable aviation. We used Västerås airport as a case example to show the lock-in and the complexity. The closing down of Västerås airport had political resistance on the middle and right section, 
and there has been no clear outcome of the future of either the aviation industry or the particular airports.

This research concludes that we can find two different kinds of discursive lock-in in the political discourse about sustainable aviation in Sweden. One is based around the perception of a technology (aviation) as being static (the technology will always be inferior to railway), which has been held in particular by the Green Party and the Left party, and that has been subscribed to the merged frame of National environmentalists' aviation. The second discursive lock-in is based around the politization of the future of the aviation industry and the difficulty to achieve a sustainable compromise on the future. This can be seen in the linkage of aviation transport with particular political parties where the green party, for instance, oppose aviation while the conservative party wants to support aviation and innovation. This polarization is actually the largest and most important aspect of the discursive lock-in as this undermines any compromises or large-scale future investments in sustainable aviation.

Author Contributions: Conceptualization, A.K. and J.N.; methodology, A.K. and J.N.; data collection, A.K.; resources, A.K.; writing-original draft preparation, A.K.; writing-review and editing, A.K and J.N. All authors have read and agreed to the published version of the manuscript.

Funding: This research was funded by Energimyndigheten as a part of the Sustainable Energy Transformation in Aviation project (Grant No. 50332-1).

Institutional Review Board Statement: Not applicable.

Informed Consent Statement: Not applicable.

Data Availability Statement: Not applicable.

Conflicts of Interest: The authors declare no conflict of interest.

\section{References}

1. Urban, F.; Nordensvärd, J. Low Carbon Energy Transitions in the Nordic Countries: Evidence from the Environmental Kuznets Curve. Energies 2018, 11, 2209. [CrossRef]

2. Adoption of the Paris Agreement; UNFCCC: Paris, France, 2015.

3. Cabuzel. European Climate Law. Clim. Action-Eur. Comm. 2020. Available online: https://ec.europa.eu/clima/policies/euclimate-action/law_en (accessed on 10 February 2021).

4. Smith, J. Sustainable Transport. Mobil. Transp.-Eur. Comm. 2016. Available online: https://ec.europa.eu/transport/themes/ sustainable_en (accessed on 10 February 2021).

5. European commission. Reducing emissions from aviation. Clim. Action-Eur. Comm. 2016. Available online: https://ec.europa. eu/clima/policies/transport/aviation_en (accessed on 10 February 2021).

6. Finansdepartementet. Available online: https://www.regeringen.se/artiklar/2018/04/sverige-ska-bli-ett-fossilfritt-valfardsland/ (accessed on 8 December 2020).

7. Sims, R.; Schaeffer, R.; Creutzig, F.; Cruz-Nunez, X.; D’Agosto, M.; Dimitriu, M. Transport; Cambridge University Press: Cambridge, UK; IPCC: New York, NY, USA, 2014.

8. Al-Ghussein Norrman, N.; Talalasova, E. Fossil-Free Aviation 2045-Actions, Obstacles and Needs. 2021. Available online: https:/ / www.diva-portal.org/smash/record.jsf?pid=diva2\%3A1523447\&dswid=-1926 (accessed on 15 February 2021).

9. Clapp, J.; Dauvergne, P. Paths to a Green World. In The Political Economy of the Global Environment; The MIT Press: Cambridge, MA, USA, 2005.

10. Sonnenchein, J.; Smedby, N. Designing air ticket taxes for climate change mitigation: Insights from a Swedish valuation Study. Clim. Policy 2019, 19, 651-663. [CrossRef]

11. Faber, J.; Huigen, T. A Study on Aviation Ticket Taxes; CE Delft: Delft, The Netherlands, 2018.

12. Faber, J.; O'leary, A. Taxing Aviation Fuels in the EU; CE Delft: Delft, The Netherlands, 2018.

13. Scheelhaase, J.; Maertens, S.; Grimme, W.; Jung, M. EU ETS versus Corsia-A Critical assessment of two approaches to limit air transport's $\mathrm{CO}_{2}$ emissions by market-based measures. J. Air Transp. Manag. 2018, 67, 55-62. [CrossRef]

14. Regeringskansliet. Remiss av Transportstyrelsens Redovisning av Regeringens Uppdrag om Miljöstyrande Start-och Landningsavgifter. Regeringskansliet. 2020. Available online: https://www.regeringen.se/remisser/2020/09/remiss-avtransportstyrelsens-redovisning-av-regeringens-uppdrag-om-miljostyrande-start--och-landningsavgifter/ (accessed on 13 February 2021).

15. Maertens, S.; Grimme, W.; Scheelhaase, J.; Jung, M. Options to Continue the EU ETS for Aviation in a Corsia-World. Sustainability 2019, 11, 5703. [CrossRef] 
16. Wang, H.; Dewil, R.; Maniatis, K.; Wheeldon, J.; Tan, T.; Baeyens, J.; Fang, Y. Biomass-derived aviation fuels: Challenges and Perspectives. Prog. Energy Combust. Sci. 2019, 74, 31-49. [CrossRef]

17. Bryngemark, E. Second generation biofuels and the competition for forest raw materials: A partial equilibrium analysis of Sweden. Policy Econ. 2019, 109, 102022. [CrossRef]

18. Schmidt, P.; Batteiger, V.; Roth, A.; Weindorf, W.; Raksha, T. Power-to-Liquids as Renewable Fuel Option for Aviation: A Review. Chem. Ing. Tech. 2018, 90, 124-140. [CrossRef]

19. Scheelhaase, J.; Maertens, S.; Grimme, W. Synthetic fuels in aviation-Current barriers and potential political measures. Transp. Res. Procedia 2019, 43, 21-30. [CrossRef]

20. Epstein, A.; O'Flarity, S. Considerations for Reducing Aviation's $\mathrm{CO}_{2}$ with Aircraft Electric Propulsion. J. Propuls Power 2019, 35 , 572-582. [CrossRef]

21. Schäfer, A.; Barrett, S.; Doyme, K.; Dray, L.; Gnadt, A.; Self, R. Technological, economic and environmental prospects of all-electric aircraft. Nat. Energy 2019, 4, 160-166. [CrossRef]

22. Sahoo, S.; Zhao, X.; Kyprianidis, K. A Review of Concepts, Benefits, and Challenges for Future Electrical Propulsion-Based Aircraft. Aerospace 2020, 7, 44. [CrossRef]

23. Larsson, J.; Kamb, A.; Nässén, J.; Åkerman, J. Measuring greenhouse gas emissions from international air travel of a country's residents methodological development and application for Sweden. Environ. Impact Assess. Rev. 2018, 72, 137-144. [CrossRef]

24. Gössling, S.; Hanna, P.; Highman, J.; Cohen, S.; Hopkins, D. Can we fly less? Evaluating the 'necessity' of air travel. J. Air Transp. Manag. 2019, 81, 101722. [CrossRef]

25. Jacobson, L.; Åkerman, J.; Giusti, M.; Bhowmik, A. Tipping to Staying on the Ground: Internationalized Knowledge of Climate Change Crucial for Transformed Air Travel Behavior. Sustainability 2020, 12, 1994. [CrossRef]

26. Swedavia. Available online: https://www.swedavia.se/omstallningen/vad-vi-gor/\#gref (accessed on 8 December 2020).

27. SAS. Available online: https://www.sasgroup.net/newsroom/press-releases/2019/sas-travelers-can-now-buy-biofuel/ (accessed on 20 February 2021).

28. NIRAS. Sustainable Jet Fuel for Aviation-Nordic Perspective on the Use of Advanced Sustainable Jet Fuel for Aviation. 2020. Available online: https:/ / www.nordicenergy.org/wp-content/uploads/2020/01/Sustainable-Jet-Fuel-Update-FinalNER.pdf (accessed on 17 February 2021).

29. Rama, M.S.; Mani, M. Discerning Rejection of Technology. SAGE Open 2013, 3. [CrossRef]

30. Markard, J.; Raven, R.; Truffer, B. Sustainability Transitions: An merging field of research and tis prospects. Res. Policy 2012, 41, 955-967. [CrossRef]

31. Unruh, G. Understanding Carbon Lock In. Energy Policy 2000, 28, 817-830. [CrossRef]

32. Unruh, G. Escaping Carbon Lock-In. Energy Policy 2002, 30, 317-325. [CrossRef]

33. Metze, T. Framing the future of fracking: Discursice lock-in or energy degrowth in the Netherlands? J. Clean. Prod. 2018, 197, 1737-1745. [CrossRef]

34. Buschmann, P.; Oels, A. The overlooked role of discourse in breaking carbon lock-in: The case of the German energy transition. Wiley Interdiscip. Rev. Clim. Chang. 2019, 10, e574. [CrossRef]

35. Gailing, L. Transforming energy systems by transforming power relations. Insights from dispositive thinking and governmentality studies. Innov. Eur. J. Soc. Sci. Res. 2016, 29, 1-19. [CrossRef]

36. Lösch, A.; Heil, R.; Schneider, C. Responsibilization through visions. J. Responsible Innov. 2017, 4, 138-156. [CrossRef]

37. Moss, T.; Becker, S.; Gailing, L. Energy Transitions and Materiality: Between Dispositives, Assemblages and Metabolisms; Palgrave Macmillan: Palgrave, UK, 2016.

38. Assche, K.; Beunen, R.; Duineveld, M. Evolutionary Governance Theory: An Introduction; Springer: Cambridge, MA, USA, 2013.

39. Hajer, M.A. The Politics of Environmental Discourse; University Press: Oxford, UK, 1995.

40. Durnova, A.; Fischer, F.; Zittoun, P. Discursive Approaches to Public Policy: Politics, Argumentation, and Deliberation; Springer: Basingstoke, UK, 2016. [CrossRef]

41. Weatherall, A.; Walton, M. The metaphorical construction of sexual experience in a speech community of New Zealand university students. Br. J. Soc. Psychol. 1999, 38, 479-498. [CrossRef]

42. Jarowski, A.; Coupland, N. The Discourse Reader; Routledge: New York, NY, USA, 2000.

43. Keller, R. Diskursforschung. Eine Einfuhrung fur SozialwissenschaftlerInnen, Wiesbaden, VS Verlag fur Sozialwissenschaften; Springer: Cambridge, MA, USA, 2004.

44. Durnova, A.; Zittoun, P. Interpretive policy analysis in a French setting: The Fifth Interpretive Policy Analysis Conference, Grenoble, June 2010. Crit. Policy Stud. 2011, 5, 103-105. [CrossRef]

45. Goffman, E. Frame Analysis; Harper Books: New York, NY, USA, 1974.

46. B'eland, D. The politics of social policy language. Soc. Policy Adm. 2005, 45, 1-18. [CrossRef]

47. Nordensvärd, J.; Ketola, M. Rethinking the Consumer Metaphor versus the Citizen Metaphor: Frame Merging and Higher Education Reform in Sweden. Soc. Policy Soc. 2019, 18, 555-575. [CrossRef]

48. Cornelissen, J.P.; Oswick, C.; Thøger, L.; Christensen, L.; Phillips, N. Metaphor in organizational research: Context, modalities and implications for research. Organ. Stud. 2008, 29, 7-22. [CrossRef]

49. Burstein, P. Bringing the public back in: Should sociologists consider the impact of public opinion on public policy? Soc. Forces 1998, 77, 27-62. [CrossRef] 
50. Fauconnier, G.; Turner, M. The Way We Think: Conceptual Blending and the Mind's Hidden Complexities; Basic Books: New York, NY, USA, 2002.

51. Cornelissen, J.P. Beyond compare: Metaphor in organization theory. Acad. Manag. Rev. 2005, 30, 751-764. [CrossRef]

52. Greenwood, R.; Raynard, M.; Kodeih, F.; Micelotta, E.; Lounsbury, M. Institutional complexity and organizational responses. Acad. Manag. Ann. 2011, 5, 317-371. [CrossRef]

53. Werner, M.; Cornelissen, J. Framing the change: Switching and blending frames and their role in instigating institutional change. Organ. Stud. 2014, 35, 1449-1472. [CrossRef]

54. Jones, J.; Peccei, J. Language and politics. In Language, Society and Power; Thomas, L., Wareing, S., Singh, I., Peccei, J., Thornborrow, J., Jones, J., Eds.; Routledge: London, UK, 2004.

55. Morgan, G. Organisationsmetaforer, Lund: Studentlitterarur; Palgrave Macmillan: London UK, 1999.

56. Charteris-Black, J. Corpus Approaches to Critical Metaphor Analysis; Palgrave Macmillan: London, UK, 2004.

57. Codd, J. The construction and deconstruction of educational policy documents. J. Educ. Policy 1988, 3, 235-247. [CrossRef]

58. Storm, S. Capitalism and Climate Change: Can the Invisible Hand Adjust the Natural Theormostat? Dev. Chang. 2009, 40, 1011-1038. [CrossRef]

59. Bello, W. Will Capitalism Survive Climate Change? ZNet. 2008. Available online: http://www.zmag.org/znet/viewArticle/17095 (accessed on 15 April 2021).

60. Speth, J.G. The Bridge at the Edge of the World. In Capitalism, the Environment and Crossing from Crisis to Sustainability; Yale University Press: New Haven, CT, USA; London, UK, 2008.

61. Moderaterna, Nationella Miljö och Klimatpolitik. Available online: https://moderaterna.se/stockholm/moderaternas-nationellamiljo-och-klimatpolitik (accessed on 16 April 2021).

62. Riksdagen, Motion Till Riksdagen 2020/21:3368 av Ulf Kristersson m fl (M). Available online: https:/ / data.riksdagen.se/fil/ EABFB320-4A49-4073-9CC7-0F60B3875634 (accessed on 16 April 2021).

63. Kristdemokraterna, Flygtrafik. Available online: https:/ / kristdemokraterna.se/politik-a-o/flygtrafik/ (accessed on 16 April 2021).

64. Riksdagen, Riksdagens Snabbprotokoll 2020/21:126. Available online: https://data.riksdagen.se/fil/D28744FF-E827-493D-B102 -6190E132789A (accessed on 16 April 2021).

65. Riksdagen, Riksdagens Snabbprotokoll 2020/21:132. Available online: https://www.riksdagen.se/sv/dokument-lagar/ dokument/protokoll/protokoll-202021132-onsdagen-den-2-juni_H809132/html (accessed on 25 July 2021).

66. The Librals, Flygpolitik. Available online: https://www.liberalerna.se/politik/flyg/ (accessed on 16 April 2021).

67. The Center Party, Infrastruktur och Trafik. Available online: https://www.centerpartiet.se/var-politik/politik-a-o/infrastrukturoch-trafik/flyg (accessed on 16 April 2021).

68. The Social Democratic Party, Mera Resor och Midre Utsläpp. Available online: https:/ /www.socialdemokraterna.se/nyheter/ nyheter/2019-03-11-mera-resor-mindre-utslapp\#0,hämtat (accessed on 16 April 2021).

69. Trafikverket, Upphandling av Fossilfritt Flyg. Available online: http://trafikverket.diva-portal.org/smash/get/diva2:1509692/ FULLTEXT01.pdf (accessed on 24 March 2021).

70. Sveriges Riksdag, Utgiftsområde 22 Kommunikationer. Available online: https://www.riksdagen.se/sv/dokument-lagar/ arende/betankande/utgiftsomrade-22-kommunikationer_H801TU1 (accessed on 10 June 2021).

71. Vänsterpartiet, Klimat. Available online: https:/ /www.vansterpartiet.se/politik/klimat/ (accessed on 16 April 2021).

72. Vänsterpartiet, Miljöpolitik. Available online: https://www.vansterpartiet.se/assets/VP_Miljopolitik_WEB12aug.pdf (accessed on 16 April 2021).

73. Sveriges Radio. Vänstern Kritiserar Flygstödet: Pengar Som Förstör Klimatet. Available online: https://sverigesradio.se/artikel/ 7495202 (accessed on 16 April 2021).

74. Miljöpartiet, Trafik. Available online: https://www.mp.se/politik/trafik (accessed on 16 April 2021).

75. Centerpartiet, Våsterås Flygplats är Lönsam! Available online: https://www.centerpartiet.se/lokal/vastmanland/vasteras/ startsida/nyheter/nyheter/2021-03-19-vasteras-flygplats-ar-lonsam (accessed on 16 April 2021).

76. SVT. Västerås Flygplats Läggs ner. Available online: https://www.svt.se/nyheter/lokalt/vastmanland/vasteras-flygplats-laggsned (accessed on 25 July 2021).

77. VLT. Ingen Anledning att Vänta Med Nedläggning. Available online: https://www.vlt.se/artikel/debatt-ingen-anledning-attvanta-med-nedlaggning (accessed on 25 July 2021).

78. Sveriges Riksdag, Riksdagens Snabbprotokoll 2020/21:132. Available online: https://data.riksdagen.se/fil/F2A923D5-AEDF4FC4-A0FA-4921D20E768F (accessed on 15 August 2021).

79. SVT. Preliminära Resultatet: 78 Procent vill Behålla Västerås Flygplats. Available online: https://www.svt.se/nyheter/lokalt/ vastmanland/sa-sager-preliminara-resultatet-av-folkomrostningen-om-vasteras-flygplats (accessed on 25 July 2021).

80. SVT, Så Reagerar Övriga Partier på Utspelet om Flygplatsen-KD: "Ett Svek Mot Våsterås". Available online: https://www.svt. se/nyheter/lokalt/vastmanland/sa-reagerar-ovriga-partier-pa-utspelet-om-flygplatsen-ett-svek-mot-vasteras (accessed on 25 July 2021).

81. SVT. Inte en Krona till Västerås Flygplats. Available online: https:/ /www.svt.se/nyheter/lokalt/vastmanland/vasteras-flygplatslaggs-ned (accessed on 15 August 2021). 
82. Miljöpartiet, Lägg ner Eller Sälj Flygplatsen! Available online: https://www.mp.se/vasteras/flygplatsen-i-vasteras (accessed on 15 August 2021).

83. SVT. M och KD vill att Region Västmanland Köper Halva Kommunala Flygplatsbolaget. Available online: https://www.svt.se/ nyheter/lokalt/vastmanland/m-och-kd-vill-att-region-vastmanland-koper-halva-kommunala-flygplatsbolaget (accessed on 15 August 2021). 